\title{
Review
}

\section{The Biology of Heat-induced DNA Double-Strand Breaks}

\author{
EIICHIRO MORI, AKIHISA TAKAHASHI, TAKEO OHNISHI* \\ Department of Biology, School of Medicine, Nara Medical University, 840 Shijo-cho, Kashihara, Nara 634-8521, \\ Japan
}

\begin{abstract}
Hyperthermia is widely used to treat patients with various types of cancers. However, the molecular mechanisms involved in heat-induced cell killing are not yet fully understood. Although protein denaturation is known to be a major type of damage caused by heat treatment, recent work has revealed that DNA double-strand breaks (DSBs) play important roles in heat-induced cell killing. The aim of this review is to specifically examine the formation and repair of DSBs and their role in heat sensitivity and thermotolerance.
\end{abstract}

Key Words: hyperthermia, DNA double-strand break, $\gamma \mathrm{H} 2 \mathrm{AX}$, endogenous DNA damage.

\section{Introduction}

Heat can lead to the denaturation of cellular structures and also affect enzymatic activities. However, the question of whether or not proteins are the sole target of heat exposure still remains to be examined $^{1)}$. In eukaryotes, DNA is primarily packaged around a histone octamer (histones $\mathrm{H} 2 \mathrm{~A}, \mathrm{H} 2 \mathrm{~B}$, $\mathrm{H} 3$ and H4) to form nucleosomes ${ }^{2,3)}$. The tails of these core histones which help to form nucleosomes can be modified by a wide range of post-translational reactions, including acetylation, phosphorylation, methylation, ubiquitination, glycosylation and ADP-ribosylation. These chromatin modifications can act as dynamic signals which are capable of coding for specific activities ${ }^{4,5)}$, and can play an important role in the regulation of diverse chromatin functions such as gene expression, DNA replication and chromosome segregation $^{6-8)}$. Recently, the measurement of $\gamma \mathrm{H} 2 \mathrm{AX}$ (histone $\mathrm{H} 2 \mathrm{AX}$ phosphorylated at serine 139) foci formation has attracted considerable attention because this data can provide very sensitive and specific signals to indicate the existence of $\mathrm{DSBs}^{9,10)}$. Heat shock has recently been reported to induce $\mathrm{DSBs}^{11)}$ and $\gamma \mathrm{H} 2 \mathrm{AX}$ focus formation ${ }^{11,12}$. The aim of this review is to examine heat-induced cell killing, along with the role and biological importance of heat-induced DSBs.

\section{DSB production}

In contrast to DNA double-strand breaks (DSBs), DNA single-strand breaks (SSBs) are frequently occurring endogenous DNA lesions in cells $\left(10^{4} / \text { cell/day }\right)^{13)}$. Failure to repair such lesions can lead to

Received 16 May, 2008, Accepted 3 June, 2008. *Corresponding author: Tel, +81-744-22-3051 (ext 2264) ; Fax, +81-744-25-3345; e-mail, tohnishi@naramed-u.ac.jp

doi : $10.3191 /$ thermalmed.24.39

(C) 2008 Japanese Society for Thermal Medicine 
mutations, genomic instability, or cell death. SSBs can be induced directly by free radicals, or more commonly as a consequence of the repair of apurinic sites caused by the depurination or repair of deaminated cytosine or other damaged bases ${ }^{13)}$. In normal human cells, it is estimated that approximately $1 \%$ of cellular single-strand lesions are converted to approximately 100 endogenous DSBs per cell per cell cycle ${ }^{14)}$. This number is similar to the number of exogenously generated DSBs produced by 1.5-2.0 Gy of sparsely ionizing radiation. Although endogenous DSBs are usually repaired with high fidelity, errors in their repair contribute significantly to the rate of cancer in humans. The doubling dose for induced DSBs is similar to the doubling doses for mutations and for the induction of carcinomas by ionizing radiation. Thus, spontaneous DNA damage could contribute significantly to the production of endogenous DNA damage at physiological temperatures ${ }^{15)}$.

$\gamma \mathrm{H} 2 \mathrm{AX}$ is widely accepted as a specific indicator for the presence of DSBs ${ }^{16)}$. Using this sensitive detection method, various factors have now been associated with DSB formation. DSBs can be caused by both exogenous agents, such as ionizing radiation and certain chemicals, as well as by endogenous agents, including the byproducts of cellular metabolism such as oxygen free radicals ${ }^{16)}$. DSBs are generated endogenously during regulated DNA transposition events in which H2AX has also been shown to play a role. Such processes include meiotic recombination ${ }^{17)}, \mathrm{V}(\mathrm{D}) \mathrm{J}$ recombination ${ }^{18)}$, heavy chain class switching ${ }^{19)}$, apoptotic DNA fragmentation ${ }^{20)}$, senescence ${ }^{21)}$ and dysfunctional telomeres ${ }^{22)}$. DSBs can also arise spontaneously in each S-phase. For example, if a SSB in a parental strand is passed by a replication fork, a DSB will result ${ }^{23)}$. In addition, the background expression of $\gamma \mathrm{H} 2 \mathrm{AX}$ in $\mathrm{S} / \mathrm{G}_{2}$-phase cells could be an indication of the presence of DSBs or stalled replication forks at damage sites introduced during normal DNA replication ${ }^{11,24)}$. Thus, it appears likely that spontaneous DNA damage could contribute significantly to the production of endogenous DSBs at physiological temperatures ${ }^{14)}$.

Besides the stresses above mentioned, hyper-osmotic stress ${ }^{25)}$, hypoxia ${ }^{6)}$ and heat ${ }^{11,12)}$ induce the formation of $\gamma \mathrm{H} 2 \mathrm{AX}$ foci. Although the mechanisms through which these types of stress induce DSBs has not yet been clarified, the occurrence of DSB production has been confirmed using pulsed-field gel electrophoresis and the comet assay ${ }^{11,26,27)}$ showing that these treatments do induce DSBs. Many investigators have reported that cellular DNA strand breaks are detected in heat-treated cells using alkaline elution methods ${ }^{12)}$, alkaline unwinding methods ${ }^{26)}$, in situ nick translation methods ${ }^{28)}$, and pulsed-field gel electrophoresis methods ${ }^{26)}$. It has also been thought that the inhibition of DNA repair under hyperosmotic conditions can lead to an increase in the number of existing DSBs, because transient DNA strand breaks are continuously created during transcription and replication ${ }^{25)}$. Inhibition of poly (ADP) ribose polymerase (PARP), which is involved in base excision repair and SSB repair, does induce $\gamma \mathrm{H} 2 \mathrm{AX}$ foci ${ }^{29)}$. It has also been hypothesized that a nick is converted to a DSB at a DNA replication fork. If so, then $\gamma \mathrm{H} 2 \mathrm{AX}$ foci might accumulate more readily when cells are heated in S-phase than when they are heated in $\mathrm{G}_{1}$-or $\mathrm{G}_{2}$-phase ${ }^{11)}$.

\section{Heat throws light on endogenous DSBs}

Spontaneous DNA damage could contribute significantly to the production of endogenous DSBs at physiological temperatures ${ }^{14)}$. According to estimates ${ }^{15)}$, spontaneous DNA damage, specifically 
single-strand lesions (SSLs), in mammalian cells could occur at a rate of several hundred to $10^{3} \mathrm{DNA}$ lesions/cell per h (approximately $10-15 / \mathrm{cell} / \mathrm{min}$ ) at $37^{\circ} \mathrm{C}$ under normal conditions (Fig. 1A). If the temperature is raised from $37^{\circ} \mathrm{C}$ to $45.5^{\circ} \mathrm{C}$, the estimated number of DNA lesions would increase 4 fold (Table I). The rate for the conversion of single strand lesions to endogenous DSBs is at least $1 \%$ at $37^{\circ} \mathrm{C}$ under normal conditions ${ }^{14)}$. Even if this conversion rate does not change at $45.5^{\circ} \mathrm{C}$, the number of endogenous DSBs would be 4 times higher at $45.5^{\circ} \mathrm{C}$ than at $37^{\circ} \mathrm{C}$. As discussed above, temperature elevations induce protein conformational changes, and can down-regulate the enzymatic activity of repair factors which are active in the repair of single strand lesions. Thus, it can easily be imagined that this conversion rate could be higher at $45.5^{\circ} \mathrm{C}$. If this estimation is used in conjunction with a report showing that heat induces $5 \gamma \mathrm{H} 2 \mathrm{AX}$ foci/cell $/ \mathrm{min}$ at $45.5^{\circ} \mathrm{C}^{11)}$, the conversion rate from spontaneous single-strand lesions to DSBs $(\gamma \mathrm{H} 2 \mathrm{AX}$ foci) would be about 9 times higher (approximately 9\%) (Fig. 1B). In addition, the conversion ratio does not increases rapidly until the temperature reaches the inflection point in the graph for protein denaturation vs $\gamma \mathrm{H} 2 \mathrm{AX}$ induction $\left(42.5^{\circ} \mathrm{C}\right)$.

Several laboratories have reported that heat induces $\gamma \mathrm{H} 2 \mathrm{AX}^{11,12,30)}$ foci. The induction of endogenous DSBs has recently been recognized ${ }^{14}$, and constitutive histone H2AX phosphorylation ${ }^{32}$ and ATM activation are used as indicators for the occurrence of DNA damage generated by endogenous oxidants $^{31}$. Taking these facts into account, $\gamma \mathrm{H} 2 \mathrm{AX}$ foci induced by heat resemble "a character written

\section{A $37^{\circ} \mathrm{C}$}

Spontaneous SSLS

Conversion rate

$(1 \%)$

\section{Endogenous DSBs}

B $45.5^{\circ} \mathrm{C}$

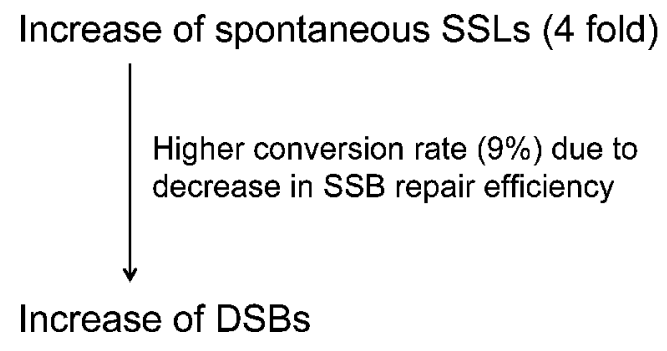

Fig. 1. A model for the production of DSBs from SSLs at different temperatures. (A) Production of endogenous DSBs at $37^{\circ} \mathrm{C}$. (B) Production of DSBs from increased numbers of SSLs and an altered conversion rate at $45.5^{\circ} \mathrm{C}$.

Table I. DNA damage at different temperatures.

\begin{tabular}{lccc}
\hline Temperature $\left({ }^{\circ} \mathrm{C}\right)$ & 37 & 42.5 & 45.5 \\
\hline Spontaneous SSL $(/$ cell/min)* & 14.3 & 34.5 & 55.1 \\
& & $(2.4$ fold increase) & (3.9 fold increase) \\
Estimated DBS arising from spontaneous SSLs (/cell/min) ${ }^{\dagger}$ & 0.143 & 0.345 & 0.551 \\
$\gamma \mathrm{H} 2 \mathrm{AX}$ focus formation $(/ \mathrm{cell} / \mathrm{min})^{\ddagger}$ & - & 0.465 & 4.825 \\
Estimated conversion rate from SSLs to DSBs $(\%)^{\S}$ & 1 & 1.3 & 8.8 \\
\hline
\end{tabular}

* $\log _{10} K=-6813 / T+24.91$

$K:$ the rate coefficient of production at a given temperature (/cell/h);T= the absolute temperature ${ }^{3)}$.

$\dagger$ When conversion factor to calculate the rate of conversion from spontaneous SSLs to DSBs at a specific temperature (1\%).

¥ According to a previous report ${ }^{11)}$.

$\S[$ Conversion rate from spontaneous SSLs to DSBs $]=[\gamma \mathrm{H} 2 \mathrm{AX}$ focus formation $] /[$ Spontaneous SSLs $]$ 
in secret ink," or in other words, heat can indicate something about endogenously produced DSBs. These indicators, constitutive histone H2AX phosphorylation ${ }^{32)}$ and ATM activation, can also be applied to the studies of other DNA damaging agents and environmental stresses which are not believed to induce DSBs.

\section{DNA polymerase $\beta$ and thermotolerance}

DNA polymerase $\beta(\mathrm{Pol} \beta)$ is a key enzyme involved in protecting the genome from DNA damage through its role in base excision repair (BER), and in mammalian cells, most BER synthesis is carried out by $\mathrm{Pol} \beta^{33,34)}$. Pol $\beta$ not only functions as a DNA polymerase, but also catalyzes the excision of deoxyribose phosphate ${ }^{35)}$. The activation enthalpy for cell killing is also similar to that of protein denaturation ${ }^{36)}$, such as that for $\operatorname{Pol} \beta^{37)}$. There is an inflection point at $42.5^{\circ} \mathrm{C}$ in the Arrhenius plot of cell killing and $\mathrm{Pol} \beta$ inactivation ${ }^{38)}$. Moreover, there is an inflection point at $42.5^{\circ} \mathrm{C}$ in the Arrhenius plot of cell killing and $\gamma \mathrm{H} 2 \mathrm{AX}$ foci formation, and the thermal activation energies for both cell killing and foci formation are almost the same above and below this inflection point ${ }^{11)}$.

Exposure of cells to a transient, non-lethal temperature elevation results in the activation of cellular stress responses, and induces a state of thermotolerance in cells which renders them resistant to subsequent lethal insults ${ }^{39)}$. Thermotolerant cells are less sensitive to hyperthermia-induced cytotoxicity, growth factor withdrawal, heavy metals, radiation and anti-cancer drugs ${ }^{40)}$. Thermotolerance is associated with the synthesis and cellular accumulation of a family of highly conserved proteins referred to as heat shock proteins (HSPs) such as Hsp27 and Hsp7041-43), and these proteins contribute to the protection of other cellular proteins, presumably due to their chaperone activity ${ }^{44,45)}$.

The widespread conservation of HSPs in organisms may be the result of selection, because HSPs can protect the genomes of cells from oxidation and radiation damage through their stimulation of DNA repair enzymes. Interestingly, Hsp70.1 and Hsp70.3, which are stress-induced HSPs, have an essential role in maintaining genomic stability under stress conditions ${ }^{46)}$. HSPs have been implicated in the induction of radiation resistance via the adaptive response ${ }^{47)}$. BER plays an important role in radiosensitivity ${ }^{48}$, and $\mathrm{Hsp} 70$ association with $\operatorname{Pol} \beta$ stimulates this activity ${ }^{49)}$. In addition, uracil DNA glycosylase and apurinic-apyrimidinic endonuclease (APE) are associated with Hsp70 and Hsp27 related BER enzymes ${ }^{50)}$. Thus, Hsp27 and Hsp70 appear likely to have a role in the repair of DNA damage.

Although HSPs are known to contribute to thermotolerance, they play only a supporting role in this phenomenon. A positive correlation was seen between thermotolerance for heat killing and the heat-induced loss of $\mathrm{Pol} \beta$ activity in cells ${ }^{51)}$, and heat-induced $\gamma \mathrm{H} 2 \mathrm{AX}$ foci formation was suppressed in cells which had developed thermotolerance ${ }^{11)}$. Moreover, $\operatorname{Pol} \beta$ contributes to thermotolerance through its reactivation and stimulation by Hsp27 and Hsp70, suggesting Pol $\beta$ functions as a critical element involved in thermotolerance and exerts an important role in cellular handling of heat-induced DSB ${ }^{52}$.

$\mathrm{Pol} \beta$ is more sensitive to heat than incision enzymes such as APE. Heat increases the basal level of base damage through the production of reactive oxygen species ${ }^{53,54)}$. At the same time, heat induced inhibition of BER would lead to an increase in the number of inappropriately repaired base damage sites, leading to an elevation in the number of nicks generated during repair attempts. Therefore, it appears that there is a possible mechanism to explain how heat induces nick formation through enzymatic repair 
processes. DSBs could then be generated where nicks form in close proximity to each other on opposite DNA strands. This theoretically provides a mechanism which could account for the increased numbers of DSBs observed in heat-treated cells (Fig. 2).

The inhibition of PARP-1, which is involved with BER, SSB repair, and the induction of $\gamma \mathrm{H} 2 \mathrm{AX}$ foci ${ }^{29}$ ), can provide additional support for the above hypothesis. Although Pol $\beta$, XRCC1 (x-ray repair cross-complementing group 1), PARP-1, and DNA ligase III (Lig3) are considered to contribute predominantly to BER and SSB repair ${ }^{55-59)}$, XRCC1, PARP-1, and Lig3 have also been reported to be candidates for components of backup repair pathways for non-homologous end joining (NHEJ) ${ }^{60-63)}$, and presumably $\operatorname{Pol} \beta$ would then also participate in these pathways. If so, then there may be a possibility that elevated temperatures could produce DSBs by inactivating these components of alternative repair pathways.

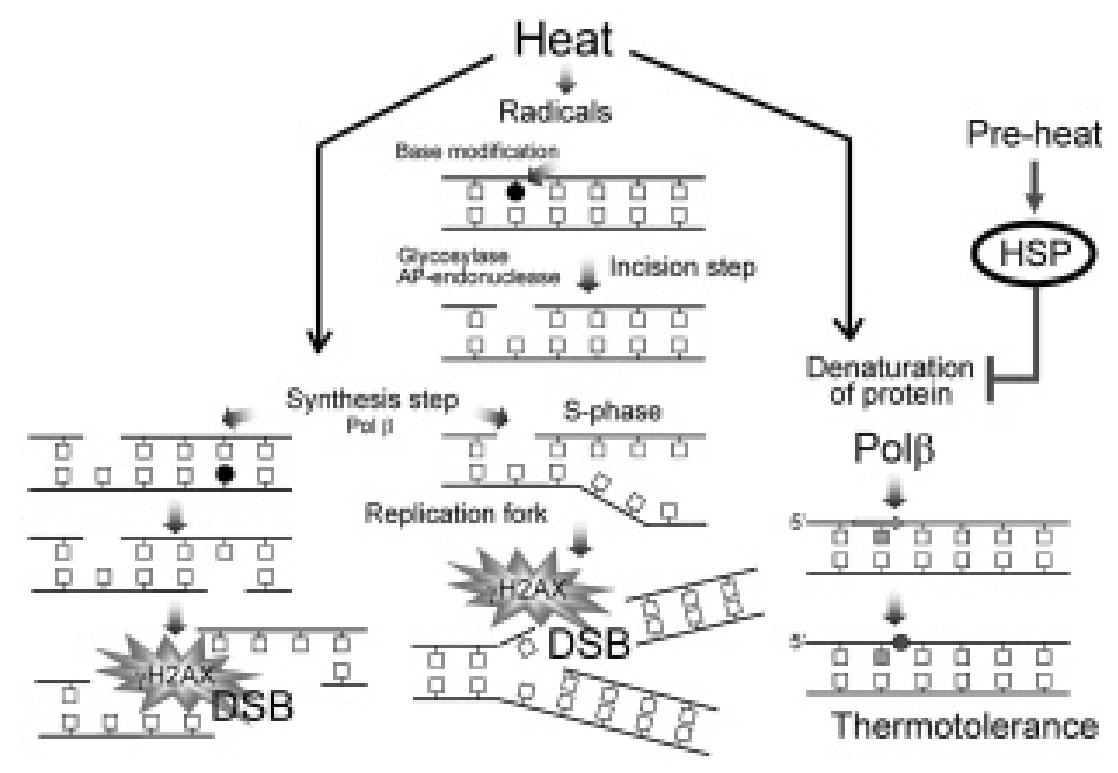

Fig. 2. A model for the production of DSBs by heat treatment. Heat induces DSBs through the BER pathway, and a pre-heating (or a conditioning) treatment induces HSPs leading to fewer DSBs during thermotolerance development.

\section{Heat interferes with DSB recognition}

DSBs are highly cytotoxic lesions, and to ensure that they are repaired with a minimal impact on genome stability, cells mount a complex DNA-damage response which includes the spatial reorganization of DSB repair and signaling proteins into sub-nuclear structures which surround DSB sites ${ }^{64,65)}$. Most ionizing radiation-induced foci formation depends on the phosphorylation of the histone variant $\mathrm{H} 2 \mathrm{AX}$ by ATM and DNA-dependent protein kinase (DNA-PK) ${ }^{66}$. The phosphorylated $\gamma \mathrm{H} 2 \mathrm{AX}$ epitope is bound by a mediator of DNA damage checkpoint 1 (MDC1) ${ }^{67,68)}$ which then promotes ionizing radiation-induced foci formation by utilizing other proteins, including p53 binding protein 1 (53BP1), Nijmegen breakage syndrome 1 (NBS1), meiotic recombination 11 (MRE11), RAD50, and the breast and ovarian cancer susceptibility protein 1 (BRCA1) ${ }^{69-72)}$. 53BP1 also interacts with DSBs via binding to 
constitutively methylated residues on histones $(\mathrm{H} 3 / \mathrm{H} 4)^{73,74)}$. Structural maintenance of chromosomes 1 (SMC1), the structural component of the multiprotein cohesin complex, has a role in DSB recognition ${ }^{75)}$, and phosphorylation of SMC1 on serine 957 (one of the key ATM target sites) allows it to co-localize with $\gamma \mathrm{H} 2 \mathrm{AX}$ foci $^{76)}$.

Many factors are known to be involved in DSB recognition, signaling, and repair pathways. However, how these proteins react in different conditions remains unclear. Heat activates ATM ${ }^{77)}$, and heat-induced H2AX phosphorylation is mediated by ATM and DNA-PK ${ }^{12}$ (Fig. 3B). In addition, NBS1 is phosphorylated and involved in cellular responses to DNA damage which are induced by heat treatment ${ }^{78)}$. However, BRCA1 is rapidly degraded after heat treatment ${ }^{79)}$. Moreover, the MRE11/ RAD50/NBS1 (MRN) complex does not form foci in the nucleus, rather the MRN complex exits from the nucleus after heat treatment ${ }^{80,81)}$ (Fig. 3C). Furthermore, phospho-ATM, 53BP1, and phospho-SMC1 do not co-localize at heat-induced $\gamma \mathrm{H} 2 \mathrm{AX}$ foci together with MDC1 foci ${ }^{30)}$. However, at $8 \mathrm{~h}$ after a heat-treatment, both phospho-NBS1 and MRE11 co-localize with $\gamma \mathrm{H} 2 \mathrm{AX}$ foci ${ }^{82)}$, indicating delayed recognition of heat-induced $\gamma \mathrm{H} 2 \mathrm{AX}$ foci by the MRN complex after heat treatment (Fig. 3D). These data are consistent with the prolonged existence of $\gamma \mathrm{H} 2 \mathrm{AX}$ foci in the nuclei after heat treatment ${ }^{11)}$, probably due to the reduced repair ability of cells exposed to heat.

A

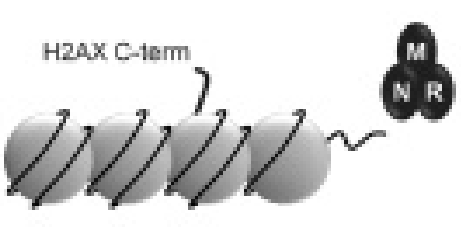

C

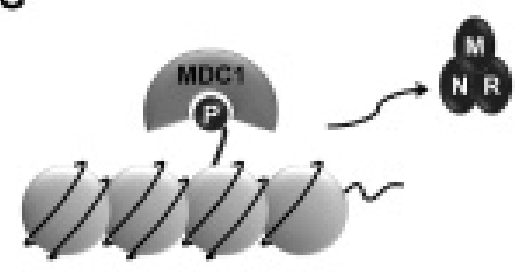

B

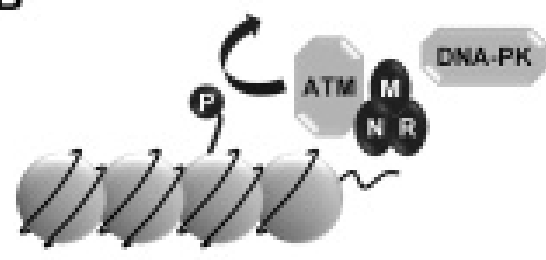

D

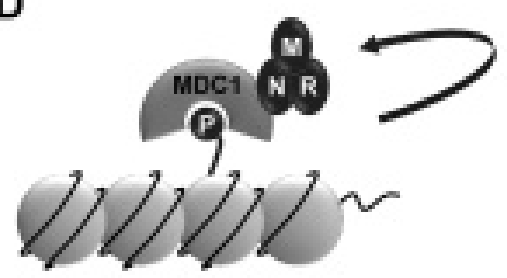

Fig. 3. A model for heat-induced DSB recognition. (A) MRN complex recognizes heat-induced DSB. (B) H2AX is phosphorylated by ATM and/or DNA-PK. (C) MDCl binds to heat-induced $\gamma \mathrm{H} 2 \mathrm{AX}$, but the MRN complex translocates from the nucleus to the cytoplasm soon after heat treatment. (D) MRN complexes accumulates and form foci in the nucleus at $8 \mathrm{~h}$ after heat treatment.

\section{Pathways for DSB repair}

Failure to repair DSBs can lead to mutations, genomic instability, or cell death. Thus, cells have developed 2 major repair pathways in which different kinds of DNA damage can be detected and repaired: these are homologous recombination (HR) and NHEJ.

$\mathrm{HR}$ is generally an error-free pathway for homology-directed repair. A DSB is accurately repaired 
by using the undamaged sister chromatid as a template for the repair of the broken sister chromatid. The proteins which function in HR include the MRN (MRE11/RAD50/NBS1) complex, RAD51, the RAD51 paralogs (RAD51B, RAD51C, RAD51D, XRCC2, XRCC3), RAD54 and RAD54B ${ }^{83)}$. The products of the breast cancer susceptibility genes, BRCA1 and BRCA2 (which are responsible for the Fanconi anemia complementation groups D1, FANCD1), are also involved in the modulation of $\mathrm{HR}^{84-86)}$.

NHEJ is the simplest way of repairing DSBs : this is the straightforward re-ligation of broken DNA ends without the requirement for a template. NHEJ plays a major role in the elimination of DSBs during the $G_{1}$-phase of the cell cycle since $H R$ is not efficient in this phase due to the lack of sister chromatids. After DSB formation, the Ku70/80 heterodimer binds to the DNA ends. This facilitates the recruitment of the DNA-PK catalytic subunit (DNA-PKcs) to the DSB. The sequential binding of these proteins activates the phosphorylation function of DNA-PKcs, which phosphorylates itself, the Ku heterodimer, and other proteins involved in cell cycle regulation ${ }^{87)}$. It has been speculated that $\mathrm{Ku} 70 / 80$ might also function as an alignment factor which binds the severed DSB ends, creating easy access for and greatly stimulating the function of the DNA ligase IV (Lig4)-XRCC4 complex, increasing the efficiency and accuracy of NHEJ ${ }^{88-90)}$. The Lig4-XRCC4 complex then ligates the juxtaposed DNA ends.

Recently, it has been suggested that several factors are involved in alternative or backup pathways for NHEJ. These pathways are independent of $\mathrm{Ku}^{91)}$ and suppressed by DNA-PK ${ }^{92)}$. Lig3 provides a major ligation activity for these other NHEJ pathways ${ }^{60,61)}$. However, very low residual ligation activity is still observed without Lig4 and Lig3, indicating other additional factors may act to ensure ligation ${ }^{93}$. PARP-1 plays a role as an additional contributing factor ${ }^{61-63,94)}$. Furthermore, histone H1 may function as a stimulatory factor in backup pathways for NHEJ ${ }^{95)}$. In addition, these backup pathways for NHEJ are markedly dependent on growth state ${ }^{96)}$, and enhanced repair activity is observed in $G_{2}$-phase ${ }^{97)}$. It is expected that additional factors will be discovered which participate in the support, not only of NHEJ, but also in HR to protect DNA from lethal DSBs.

Compared to the observed kinetics for radiation-induced $\gamma \mathrm{H} 2 \mathrm{AX}$ foci, the rate of decrease in the number of heat-induced $\gamma \mathrm{H} 2 \mathrm{AX}$ foci is slower ${ }^{11)}$. This can be explained if some of the major components of conventional DSB repair pathways (NHEJ or HR) were disrupted or affected by heat treatment. Analysis of heat sensitivity in several radiation sensitive cell lines showed a weak correlation between radiation sensitivity and heat sensitivity ${ }^{98}$. However, this analysis was done for only a few cell lines which were radiation sensitive. Thus, it is too soon to conclude that the gene products involved in DSB repair do not play important roles in heat induced cell killing. Certainly, further study is required to learn more about this complex phenomenon.

\section{Conclusion}

DSB production generated by exposure to heat has recently been observed to occur, and an involvement of $\mathrm{Pol} \beta$ in DSB production and thermotolerance has been shown. Delayed recognition of $\gamma \mathrm{H} 2 \mathrm{AX}$ foci by the MRN complex also contributes to slower repair kinetics for heat-induced DSBs. However, whether the repair process for heat-induced DSBs utilizes the same pathways which used for the repair of radiation-induced DSBs remains unknown. Further studies are still necessary to learn how heat-induced DSBs are recognized and repaired. 


\section{Acknowledgment}

This work was supported by Grants-in Aid for Scientific Research from the Ministry of Education, Culture, Sports, Science and Technology of Japan.

\section{References}

1) Takahashi A., Ohnishi T.: What is the critical hyperthermia target in cancer cells? Jpn J Hyperthermic Oncol, 22 : 229-237, 2006.

2) Luger K., Mäder A.W., Richmond R.K., Sargent D.F., Richmond T.J. : Crystal structure of the nucleosome core particle at 2.8 A resolution. Nature, 389: 251-260, 1997.

3) Kouzarides T.: Histone methylation in transcriptional control. Curr Opin Genet Dev, 12: 198-209, 2002.

4) Jenuwein T., Allis C.D.: Translating the histone code. Science, 293 : 1074-1080, 2001.

5) Turner B.M. : Cellular memory and the histone code. Cell, 111: 285-291, 2002.

6) Spencer V.A., Davie J.R. : Role of covalent modifications of histones in regulating gene expression. Gene, 240: 1-12, 1999.

7) Turner B.M. : Histone H4, the cell cycle and a question of integrity. Bioessays, 17 : 1013-1015, 1995.

8) Zhang Y., Reinberg D.: Transcription regulation by histone methylation: interplay between different covalent modifications of the core histone tails. Genes Dev, 15: 2343-2360, 2001.

9) Sedelnikova O.A., Rogakou E.P., Panyutin I.G., Bonner W.M.: Quantitative detection of ${ }^{125}$ IdU-induced DNA double-strand breaks with $\gamma$-H2AX antibody. Radiat Res, 158: 486-492, 2002.

10) Rothkamm K., Löbrich M. : Evidence for a lack of DNA double-strand break repair in human cells exposed to very low x-ray doses. Proc Natl Acad Sci USA, 100: 5057-5062, 2003.

11) Takahashi A., Matsumoto H., Nagayama K., Kitano M., Hirose S., Tanaka H., Mori E., Yamakawa N., Yasumoto J., Yuki K., Ohnishi K., Ohnishi T. : Evidence for the involvement of double-strand breaks in heat-induced cell killing. Cancer Res, $64: 8839-8845,2004$.

12) Kaneko H., Igarashi K., Kataoka K., Miura M.: Heat shock induces phosphorylation of histone H2AX in mammalian cells. Biochem Biophys Res Commun, 328 : 1101-1106, 2005.

13) Lindahl T. : Instability and decay of the primary structure of DNA. Nature, 362: 709-715, 1993.

14) Vilenchik M.M., Knudson A.G.: Endogenous DNA double-strand breaks: production, fidelity of repair, and induction of cancer. Proc Natl Acad Sci USA, 100: 12871-12876, 2003.

15) Vilenchik M.M., Knudson A.G Jr. : Inverse radiation dose-rate effects on somatic and germ-line mutations and DNA damage rates. Proc Natl Acad Sci USA, 97 : 5381-5386, 2000.

16) Takahashi A., Ohnishi T.: Does $\gamma \mathrm{H} 2 \mathrm{AX}$ foci formation depend on the presence of DNA double strand breaks? Cancer Lett, 229: 171-179, 2005.

17) Mahadevaiah S.K., Turner J.M., Baudat F., Rogakou E.P., de Boer P., Blanco-Rodriguez J., Jasin M., Keeney S., Bonner W.M., Burgoyne P.S. : Recombinational DNA double-strand breaks in mice precede synapsis. Nat Genet, 27 : 271-276, 2001.

18) Klein S., Zenvirth D., Dror V., Barton A.B., Kaback D.B., Simchen G. : Patterns of meiotic double-strand breakage on native and artificial yeast chromosomes. Chromosoma, 105: 276-284, 1996.

19) Petersen S., Casellas R., Reina-San-Martin B., Chen H.T., Difilippantonio M.J., Wilson P.C., Hanitsch L., Celeste A., Muramatsu M., Pilch D.R., Redon C., Ried T., Bonner W.M., Honjo T., Nussenzweig M.C., Nussenzweig A. : AID is required to initiate $\mathrm{Nbs} 1 / \gamma-\mathrm{H} 2 \mathrm{AX}$ focus formation and mutations at sites of class switching. Nature, $414: 660-665$, 2001.

20) Rogakou E.P., Nieves-Neira W., Boon C., Pommier Y., Bonner W.M.: Initiation of DNA fragmentation during 
apoptosis induces phosphorylation of H2AX histone at serine 139. J Biol Chem, 275 : 9390-9395, 2000.

21) Sedelnikova O.A., Horikawa I., Zimonjic D.B., Popescu N.C., Bonner W.M., Barrett J.C. : Senescing human cells and ageing mice accumulate DNA lesions with unrepairable double-strand breaks. Nat Cell Biol, 6: 168-170, 2004.

22) Hao L.Y., Strong M.A., Greider C.W. : Phosphorylation of H2AX at short telomeres in T cells and fibroblasts. J Biol Chem, 279: 45148-45154, 2004.

23) Helleday T., Lo J., van Gent D.C., Engelward B.P.: DNA double-strand break repair: from mechanistic understanding to cancer treatment. DNA Repair, 6: 923-935, 2007.

24) MacPhail S.H., Banáth J.P., Yu Y., Chu E., Olive P.L.: Cell cycle-dependent expression of phosphorylated histone H2AX : reduced expression in unirradiated but not X-irradiated $\mathrm{G}_{1}$-phase cells. Radiat Res, 159: 759-767, 2003.

25) Dmitrieva N.I., Bulavin D.V., Burg M.B.: High $\mathrm{NaCl}$ causes Mrel1 to leave the nucleus, disrupting DNA damage signaling and repair. Am J Physiol Renal Physiol, 285: F266-F274, 2003.

26) Wong R.S., Dynlacht J.R., Cedervall B., Dewey W.C.: Analysis by pulsed-field gel electrophoresis of DNA double-strand breaks induced by heat and/or X-irradiation in bulk and replicating DNA of CHO cells. Int J Radiat Biol, 68 : 141-152, 1995.

27) Kültz D., Chakravarty D. : Hyperosmolality in the form of elevated $\mathrm{NaCl}$ but not urea causes DNA damage in murine kidney cells. Proc Natl Acad Sci USA, 98 : 1999-2004, 2001.

28) Anai H., Maehara Y., Sugimachi K.: In situ nick translation method reveals DNA strand scission in HeLa cells following heat treatment. Cancer Lett, $40: 33-38,1988$.

29) Bryant H.E., Schultz N., Thomas H.D., Parker K.M., Flower D., Lopez E., Kyle S., Meuth M., Curtin N.J., Helleday T. : Specific killing of BRCA2-deficient tumours with inhibitors of poly (ADP-ribose) polymerase. Nature, 434 : 913-917, 2005.

30) Hunt C.R., Pandita R.K., Laszlo A., Higashikubo R., Agarwal M., Kitamura T., Gupta A., Rief N., Horikoshi N., Baskaran R., Lee J.H., Löbrich M., Paull T.T., Roti Roti J.L., Pandita T.K.: Hyperthermia activates a subset of ataxia-telangiectasia mutated effectors independent of DNA strand breaks and heat shock protein 70 status. Cancer Res, 67 : 3010-3017, 2007.

31) Tanaka T., Halicka H.D., Huang X., Traganos F., Darzynkiewicz Z. : Constitutive histone H2AX phosphorylation and ATM activation, the reporters of DNA damage by endogenous oxidants. Cell Cycle, 5 : 1940-1945, 2006.

32) Yu T., MacPhail S.H., Banáth J.P., Klokov D., Olive P.L. : Endogenous expression of phosphorylated histone H2AX in tumors in relation to DNA double-strand breaks and genomic instability. DNA Repair, 5: 935-946, 2006.

33) Sobol R.W., Horton J.K., Kühn R., Gu H., Singhal R.K., Prasad R., Rajewsky K., Wilson S.H.: Requirement of mammalian DNA polymerase- $\beta$ in base-excision repair. Nature, 379: 183-186, 1996.

34) Sobol R.W., Prasad R., Evenski A., Baker A., Yang X.P., Horton J.K., Wilson S.H.: The lyase activity of the DNA repair protein $\beta$-polymerase protects from DNA-damage-induced cytotoxicity. Nature, 405: 807-810, 2000.

35) Matsumoto Y., Kim K. : Excision of deoxyribose phosphate residues by DNA polymerase $\beta$ during DNA repair. Science, 269: 699-702, 1995.

36) Dewey W.C. : Arrhenius relationships from the molecule and cell to the clinic. Int J Hyperthermia, 10 : 457-483, 1994.

37) Spiro I.J., Denman D.L., Dewey W.C. : Effect of hyperthermia on CHO DNA polymerases $\alpha$ and $\beta$. Radiat Res, 89 : 134-149, 1982.

38) Spiro I.J., Denman D.L., Dewey W.C. : Effect of hyperthermia on isolated DNA polymerase- $\beta$. Radiat Res, 95 : 68-77, 1983.

39) Li G.C., Mivechi N.F., Weitzel G. : Heat shock proteins, thermotolerance, and their relevance to clinical hyperthermia. Int J Hyperthermia, $11:$ 459-488, 1995.

40) Takayama S., Reed J.C., Homma S. : Heat-shock proteins as regulators of apoptosis. Oncogene, 22 : 9041-9047, 2003.

41) Li G.C., Werb Z.: Correlation between synthesis of heat shock proteins and development of thermotolerance in 
Chinese hamster fibroblasts. Proc Natl Acad Sci USA, 79: 3218-3222, 1982.

42) Crête P., Landry J. : Induction of HSP27 phosphorylation and thermoresistance in Chinese hamster cells by arsenite, cycloheximide, A23187, and EGTA. Radiat Res, 121 : 320-327, 1990.

43) Ohnishi K., Takahashi A., Yokota S., Ohnishi T. : Effects of a heat shock protein inhibitor KNK437 on heat sensitivity and heat tolerance in human squamous cell carcinoma cell lines differing in p53 status. Int J Radiat Biol, 80 : 607-614, 2004.

44) Ehrnsperger M., Graber S., Gaestel M., Buchner J. : Binding of non-native protein to Hsp25 during heat shock creates a reservoir of folding intermediates for reactivation. EMBO J, 16: 221-229, 1997.

45) Hartl F.U., Hayer-Hartl M. : Molecular chaperones in the cytosol : From nascent chain to folded protein. Science, 295 : 1852-1858, 2002.

46) Hunt C.R., Dix D.J., Sharma G.G., Pandita R.K., Gupta A., Funk M., Pandita T.K.: Genomic instability and enhanced radiosensitivity in Hsp70.1-and Hsp70.3-deficient mice. Mol Cell Biol, 24 : 899-911, 2004.

47) Lee Y.J., Park G.H., Cho H.N., Cho C.K., Park Y.M., Lee S.J., Lee Y.S. : Induction of adaptive response by low-dose radiation in RIF cells transfected with Hspb1 (Hsp25) or inducible Hspa (Hsp70). Radiat Res, 157 : 371-377, 2002.

48) Vens C., Dahmen-Mooren E., Verwijs-Janssen M., Blyweert W., Graversen L., Bartelink H., Begg A.C.: The role of DNA polymerase $\beta$ in determining sensitivity to ionizing radiation in human tumor cells. Nucleic Acids Res, 30 : 2995-3004, 2002.

49) Mendez F., Kozin E., Bases R. : Heat shock protein 70 stimulation of the deoxyribonucleic acid base excision repair enzyme polymerase $\beta$. Cell Stress Chaperones, 8: 153-161, 2003.

50) Mendez F., Sandigursky M., Franklin W.A., Kenny M.K., Kureekattil R., Bases R.: Heat-shock proteins associated with base excision repair enzymes in HeLa cells. Radiat Res, 153: 186-195, 2000.

51) Dewey W.C., Esch J.L. : Transient thermal tolerance : cell killing and polymerase activities. Radiat Res, 92: 611-614, 1982.

52) Takahashi A., Yamakawa N., Mori E., Ohnishi K., Yokota S., Sugo N., Aratani Y., Koyama H., Ohnishi T.: Development of thermotolerance requires interaction between polymerase- $\beta$ and heat shock proteins. Cancer Sci, 99 : 973-978, 2008.

53) Bruskov V.I., Malakhova L.V., Masalimov Z.K., Chernikov A.V.: Heat-induced formation of reactive oxygen species and 8-oxoguanine, a biomarker of damage to DNA. Nucleic Acids Res, 30 : 1354-1363, 2002.

54) Eigner J., Boedtker H., Michaels G. : The thermal degradation of nucleic acids. Biochim Biophys Acta, 51: 165-168, 1961.

55) Caldecott K.W., McKeown C.K., Tucker J.D., Ljungquist S., Thompson L.H. : An interaction between the mammalian DNA repair protein XRCC1 and DNA ligase III. Mol Cell Biol, 14: 68-76, 1994.

56) Caldecott K.W., Tucker J.D., Stanker L.H., Thompson L.H. : Characterization of the XRCC1-DNA ligase III complex in vitro and its absence from mutant hamster cells. Nucleic Acids Res, 23: 4836-4843, 1995.

57) Cappelli E., Taylor R., Cevasco M., Abbondandolo A., Caldecott K., Frosina G. : Involvement of XRCC1 and DNA ligase III gene products in DNA base excision repair. J Biol Chem, 272 : 23970-23975, 1997.

58) Mackey Z.B., Niedergang C., Murcia J.M., Leppard J., Au K., Chen J., de Murcia G., Tomkinson A.E. : DNA ligase III is recruited to DNA strand breaks by a zinc finger motif homologous to that of poly (ADP-ribose) polymerase. Identification of two functionally distinct DNA binding regions within DNA ligase III. J Biol Chem, 274 : 21679-21687, 1999.

59) Wong H.K., Wilson D.M. 3rd. : XRCC1 and DNA polymerase $\beta$ interaction contributes to cellular alkylating-agent resistance and single-strand break repair. J Cell Biochem, 95 : 794-804, 2005.

60) Wang H., Rosidi B., Perrault R., Wang M., Zhang L., Windhofer F., Iliakis G. : DNA ligase III as a candidate component of backup pathways of nonhomologous end joining. Cancer Res, 65: 4020-4030, 2005. 
61) Audebert M., Salles B., Calsou P. : Involvement of poly (ADP-ribose) polymerase-1 and XRCC1/DNA ligase III in an alternative route for DNA double-strand breaks rejoining. J Biol Chem, 279: 55117-55126, 2004.

62) Audebert M., Salles B., Weinfeld M., Calsou P. : Involvement of polynucleotide kinase in a poly (ADP-ribose) polymerase-1-dependent DNA double-strand breaks rejoining pathway. J Mol Biol, 356 : 257-265, 2006.

63) Audebert M., Salles B., Calsou P.: Effect of double-strand break DNA sequence on the PARP-1 NHEJ pathway. Biochem Biophys Res Commun, 369: 982-988, 2008.

64) Bartek J., Lukas J. : DNA damage checkpoints : from initiation to recovery or adaptation. Curr Opin Cell Biol, 19 : 238-245, 2007.

65) Maser R.S., Monsen K.J., Nelms B.E., Petrini J.H. : hMre11 and hRad50 nuclear foci are induced during the normal cellular response to DNA double-strand breaks. Mol Cell Biol, 17: 6087-6096, 1997.

66) Stiff T., O’Driscoll M., Rief N., Iwabuchi K., Löbrich M., Jeggo P.A. : ATM and DNA-PK function redundantly to phosphorylate H2AX after exposure to ionizing radiation. Cancer Res, 64 : 2390-2396, 2004.

67) Lee M.S., Edwards R.A., Thede G.L., Glover J.N. : Structure of the BRCT repeat domain of MDC1 and its specificity for the free COOH-terminal end of the $\gamma$-H2AX histone tail. J Biol Chem, 280 : 32053-32056, 2005.

68) Stucki M., Clapperton J.A., Mohammad D., Yaffe M.B., Smerdon S.J., Jackson S.P.: MDC1 directly binds phosphorylated histone H2AX to regulate cellular responses to DNA double-strand breaks. Cell, 123 : 1213-1226, 2005.

69) Nelms B.E., Maser R.S., MacKay J.F., Lagally M.G., Petrini J.H. : In situ visualization of DNA double-strand break repair in human fibroblasts. Science, $280:$ 590-592, 1998.

70) Stewart G.S., Wang B., Bignell C.R., Taylor A.M., Elledge S.J. : MDC1 is a mediator of the mammalian DNA damage checkpoint. Nature, 421: 961-966, 2003.

71) Goldberg M., Stucki M., Falck J., D’Amours D., Rahman D., Pappin D., Bartek J., Jackson S.P. : MDC1 is required for the intra-S-phase DNA damage checkpoint. Nature, $421:$ 952-956, 2003.

72) Lou Z., Minter-Dykhouse K., Wu X., Chen J.: MDC1 is coupled to activated CHK2 in mammalian DNA damage response pathways. Nature, $421:$ 957-961, 2003.

73) Botuyan M.V., Lee J., Ward I.M., Kim J.E., Thompson J.R., Chen J., Mer G.: Structural basis for the methylation state-specific recognition of histone H4-K20 by 53BP1 and Crb2 in DNA repair. Cell, 127: 1361-1373, 2006.

74) Huyen Y., Zgheib O., Ditullio R.A.Jr., Gorgoulis V.G., Zacharatos P., Petty T.J., Sheston E.A., Mellert H.S., Stavridi E.S., Halazonetis T.D.: Methylated lysine 79 of histone H3 targets 53BP1 to DNA double-strand breaks. Nature, 432 : 406-411, 2004.

75) Kim J.S., Krasieva T.B., LaMorte V., Taylor A.M., Yokomori K.: Specific recruitment of human cohesin to laser-induced DNA damage. J Biol Chem, 277: 45149-45153, 2002.

76) Kitagawa R., Bakkenist C.J., McKinnon P.J., Kastan M.B. : Phosphorylation of SMC1 is a critical downstream event in the ATM-NBS1-BRCA1 pathway. Genes Dev, $18:$ 1423-1438, 2004.

77) Miyakoda M., Suzuki K., Kodama S., Watanabe M. : Activation of ATM and phosphorylation of p53 by heat shock. Oncogene, 21 : 1090-1096, 2002.

78) Ohnishi K., Scuric Z., Yau D., Schiestl R.H., Okamoto N., Takahashi A., Ohnishi T. : Heat-induced phosphorylation of NBS1 in human skin fibroblast cells. J Cell Biochem, 99: 1642-1650, 2006.

79) Xian Ma Y., Fan S., Xiong J., Yuan R.Q., Meng Q., Gao M., Goldberg I.D., Fuqua S.A., Pestell R.G., Rosen E.M. : Role of BRCA1 in heat shock response. Oncogene, 22: 10-27, 2003.

80) Zhu W.G., Seno J.D., Beck B.D., Dynlacht J.R.: Translocation of MRE11 from the nucleus to the cytoplasm as a mechanism of radiosensitization by heat. Radiat Res, 156: 95-102, 2001.

81) Seno J.D., Dynlacht J.R. : Intracellular redistribution and modification of proteins of the Mre11/Rad50/Nbs1 DNA repair complex following irradiation and heat-shock. J Cell Physiol, 199: 157-170, 2004.

82) Takahashi A., Mori E., Ohnishi T. : Phospho-Nbs1 and Mre11 proteins which recognize DSBs co-localize with $\gamma \mathrm{H} 2 \mathrm{AX}$ 
in the nucleus after heat treatment. Ann Cancer Res Therap, 15: 50-53, 2007.

83) Dudas A., Chovanec M. : DNA double-strand break repair by homologous recombination. Mutat Res, 566 : 131-167, 2004.

84) Moynahan M.E., Chiu J.W., Koller B.H., Jasin M.: Brcal controls homology-directed DNA repair. Mol Cell, 4 : 511-518, 1999.

85) Moynahan M.E., Pierce A.J., Jasin M. : BRCA2 is required for homology-directed repair of chromosomal breaks. Mol Cell, $7:$ 263-272, 2001.

86) Davies A.A., Masson J.Y., McIlwraith M.J., Stasiak A.Z., Stasiak A., Venkitaraman A.R., West S.C. : Role of BRCA2 in control of the RAD51 recombination and DNA repair protein. Mol Cell, 7 : 273-282, 2001.

87) Weterings E., van Gent D.C. : The mechanism of non-homologous end-joining : a synopsis of synapsis. DNA Repair, 3: 1425-1435, 2004.

88) Feldmann E., Schmiemann V., Goedecke W., Reichenberger S., Pfeiffer P. : DNA double-strand break repair in cell-free extracts from Ku80-deficient cells : implications for Ku serving as an alignment factor in non-homologous DNA end joining. Nucleic Acids Res, 28 : 2585-2596, 2000.

89) Pfeiffer P., Goedecke W., Kuhfittig-Kulle S., Obe G. : Pathways of DNA double-strand break repair and their impact on the prevention and formation of chromosomal aberrations. Cytogenet Genome Res, 104 : 7-13, 2004.

90) Thode S., Schafer A., Pfeiffer P., Vielmetter W. : A novel pathway of DNA end-to-end joining. Cell, 60 : 921-928, 1990.

91) Wang H., Perrault A.R., Takeda Y., Qin W., Wang H., Iliakis G. : Biochemical evidence for Ku-independent backup pathways of NHEJ. Nucleic Acids Res, 31 : 5377-5388, 2003.

92) Perrault R., Wang H., Wang M., Rosidi B., Iliakis G. : Backup pathways of NHEJ are suppressed by DNA-PK. J Cell Biochem, 92 : 781-794, 2004.

93) Windhofer F., Wu W., Iliakis G. : Low levels of DNA ligases III and IV sufficient for effective NHEJ. J Cell Physiol, $213:$ 475-483, 2007.

94) Wang M., Wu W., Wu W., Rosidi B., Zhang L., Wang H., Iliakis G. : PARP-1 and Ku compete for repair of DNA double strand breaks by distinct NHEJ pathways. Nucleic Acids Res, 34 : 6170-6182, 2006.

95) Rosidi B., Wang M., Wu W., Sharma A., Wang H., Iliakis G. : Histone H1 functions as a stimulatory factor in backup pathways of NHEJ. Nucleic Acids Res, 36: 1610-1623, 2008.

96) Windhofer F., Wu W., Wang M., Singh SK., Saha J., Rosidi B., Iliakis G. : Marked dependence on growth state of backup pathways of NHEJ. Int J Radiat Oncol Biol Phys, 68 : 1462-1470, 2007.

97) Wu W., Wang M., Wu W., Singh S.K., Mussfeldt T., Iliakis G. : Repair of radiation induced DNA double strand breaks by backup NHEJ is enhanced in $\mathrm{G}_{2}$. DNA Repair, $7:$ 329-338, 2008.

98) Kampinga H.H., Laszlo A. : DNA double strand breaks do not play a role in heat-induced cell killing. Cancer Res, $65: 10632-10633,2005$. 